\title{
Palynofacies in Lower Jurassic epicontinental deposits of Poland: tool to interpret sedimentary environments
}

\author{
1 Polish Geological Institute, Rakowiecka 4, Poland. E-mail: grzegorz.pienkowski@pgi.gov.pl \\ 2 Polish Geological Institute, Rakowiecka 4, Poland. E-mail: marta.waksmundzka@pgi.gov.pl
}

Diversified continental, marginal-marine and marine epicontinental deposits in Poland of Early Jurassic age yielded unusually rich palynomacerals. Numerous parameters, such as the presence of acritarchs and dinoflagellate cysts, spore/bisaccate pollen grain ratio, content of terrestrial phytoclasts, degree of oxidation, presence of tetrads and sporangia, degree of palynomorph alteration, presence and character of amorphous organic matter, presence of epibionts on palynomorphs, were collectively found as indicative of certain palynofacies. The ratio of spores and bisaccate pollen grains significantly depends on the climatic conditions where also seasonal changes may influence the local characteristics of palynofacies. However, the ratio also strongly reflects the local depositional environment which may vary regionally and spore/bisaccate pollen grain ratio can be taken as a general indicator of distance from the shore. Early Jurassic palynomacerals from the Polish Basin are strongly dominated by terrestrial elements, marine palynomacerals occur in significant quantities only in Pliensbachian deposits in Pomerania Western Poland. Charcoal is an important component of palynomacerals. Due to its resistance to biogenic degradation and buoyancy, charcoal produced by extensive wildfires was widely re-deposited and concentrated particularly in foreshore to shallow shoreface and delta plain environments. Three types of palynofacies inversions (abnormal palynofacies composition) are discussed. Six main palynofacies types linked to depositional systems previously determined by sedimentological studies have been distinguished providing a robust paleoenvironmental tool for recognition of palynofacies attributed to certain palaeoenvironments.

\section{Introduction}

Since the pioneering work of Muller (1959), distribution patterns of palynomorphs and other particulate organic matter has been used for facies recognition and palaeoenvironmental interpretation. Palynofacies forms a natural interface between palynology and sedimentology. The term palynofacies, introduced by Combaz (1964), embracing all HF resistant organic remains in sediments, involves recognition of different types of palynomorps, phytoclasts, amorphous organic matter, their proportions, size spectra and preservation states. Palynofacies analysis has been particularly developed by Batten (1973, 1996) and Tyson (1984, 1987, 1989, 1993, 1995) and other authors (Tschudy, 1969; Minshall et al. 1985, Bustin 1988, Van Bergen and Kerp, 1990, Williams, 1992). The definition of Powell et al. (1990) stating that palynofacies signify a distinctive assemblage of palynoclasts (or palynological matter, kerogen, palynomacerals), whose composition reflects a particular sedimentary environment was adopted by the present authors.

Unusually rich palynofacies of the epicontinental Lower Jurassic deposits of Poland, coupled with great range of palaeoenvironments, previously determined by detailed sedimentological studies (Pieñkowski, 2004), offered a good opportunity to study the palynofacies/palaeoenvironment interface in detail. The scope of this paper is to link sedimentary palaeoenvironments, interpreted based on detailed sedimentological studies, to the related palynofacies.

\section{Geological, sedimentological and palaeoclimatological background}

During the Early Jurassic, spanning some 24 million years (Gradstein et al. 2004), terrigenous, continental, marginal-marine and marine sediments reaching a maximum of $1400 \mathrm{~m}$ in thickness were deposited in a large epeiric basin extending across Poland (Figs. 1, 2). The sediments are defined as the Kamienna Group (Pieñkowski, 2004), that was subdivided into lithologic formations (Fig. 2), showing regional facies differentiation (Pieñkowski, 2004). The Mid-Polish Trough was an elongated, relatively narrow subsiding zone, which was superimposed on the south-western edge of the East European Craton and the north eastern boundary of the Variscides (Dadlez, 1997; Fig. 1). The Lower Jurassic deposits are dated with varied precision marine deposits in Pomerania yielded Pliensbachian ammonites, in the other parts of the basin the less precise biostratigraphic divisions are based on megaspores (Marcinkiewicz, 1971), miospores (Pieñkowski 2004) and dinoflagellate cysts (Barski and Leonowicz, 2002; Pieñkowski, 2004).

Detailed studies performed in 35 cored boreholes and exposures integrated data from lithology, sedimentary structures, trace fossils, 


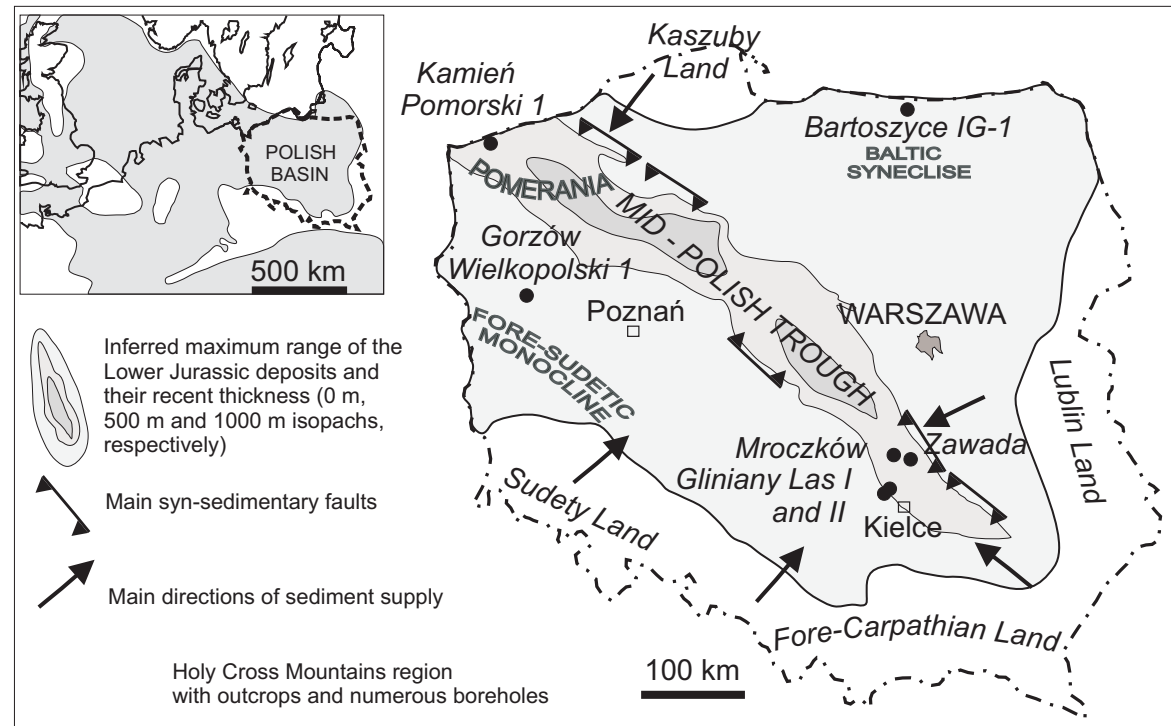

Figure 1. Paleogeographic map of the Early Jurassic epicontinental basin in Poland. Main parts of the basin (or regions) are indicated, as well as location of seven boreholes sampled for palynomacerals.

body fossils, boron content and petrology (Fig. 3). It allowed lithofacies description, palaeosalinity reconstruction, recognition of depositional systems, and sequence stratigraphic correlation (Pieñkowski, 2004) - Figs. 2, 3.

During the Early Jurassic, marginal-marine (mainly mesohaline), deltaic and continental sedimentation prevailed in the area of Poland. Marine (polyhaline) conditions occurred mainly in the Pliensbachian times (in Pomerania and briefly in the rest of the Mid-Polish Trough). Also some thin horizons within the Sinemurian and Toarcian sections in Pomerania show marine characteristics (Pieñkowski, 2004). The Early Jurassic Polish basins in (irrespectively of its marine or brackishmarine character) were generally not deeper than few tens of metres, most commonly their depth varied between 10 and $20 \mathrm{~m}$ (Pieñkowski, 2004). It means that the wave-base could reach the bottom of the basin and consequently dispersal of sediments and palynomacerals, enhanced by nearshore currents, was very extensive. Only the Early Pliensbachian sedimentation in Pomerania took place in a shelf basin attaining depth of about $100 \mathrm{~m}$, below the storm wave base. Early Jurassic shallow marginal-marine, marine-brackish environments in Poland are characterised by a low diversity but abundant, mainly oligohaline-mesohaline biota. Brackish-water bivalves (mostly Cardiinidae and Mytiliidae) occur in the assemblages in high numbers but in low diversity, foraminifera are mostly represented by impoverished assemblages of agglutinated forms. Brackish marine trace fossil assemblages are generally richer and more diversified than fresh-water assemblages (Pieñkowski 1985), but locally terrestrial ichnoassemblages are rather diversified (Pieñkowski and Niedzwiedzki, 2007 in print).

Shallow brackish-marine or marine reservoirs were fringed by barrier-lagoon and deltaic environments. Deltas were both of fluvialdominated (bird-foot) character or wave-dominated with fringing barrier and lagoons. Behind these marginal-marine facies belt (of deltaic/barrier-lagoon origin) alluvial plains developed. Alluvial environments were dominated by meandering and anastomosing river systems (Pieñkowski, 2004).

Sedimentation in the extensive and shallow Polish Basin was characterized by a great variety of rapidly shifting facies and depositional systems and reflects even minor fluctuations in sea level (Pieñkowski, 1991, 2004). This allowed a high-resolution sedimentological and sequence stratigraphic analysis (Pieñkowski, 1991, 2004) (Fig.3). Eleven sequences has been distinguished (Fig. 2), comparable to the number of global Early Jurassic sequences determined by Haq et al. (1987). Sequences are divided into parasequences (Fig. 3). Boundaries of sequences and most of the parasequences in the Lower Jurassic of Poland can be compared to the European standards (Hesselbo and Jenkyns, 1998; De Graciansky et al. 1998). Total number of parasequences in the Lower Jurassic of the Polish Basin is similar to the number of sequences (24) determined in British Lias by De Graciansky et al. (1998).

Traces of vegetation such as plant roots and palaeosol horizons are common in the Early Jurassic deposits. Palaeosols mark hiatuses in sedimentation and are often associated with tops of shallowing-upward sequences and parasequences (Fig. 3). Proximity of marsh/swamp area had a crucial impact on palynofacies. Numerous finds of macroscopic plant fossils have been helpful in interpreting of palaeoclimatic conditions (Makarewiczówna, 1928; Reymanówna, 1991; Wcislo-Luraniec, 1991), pointing generally to a warm and fairly humid climate, conductive for dense vegetation. It is concordant with general reconstruction of the Early Jurassic palaeoclimate (Chandler et al. 1992). The general miospore spectra with a domination of Matoniaceae and Dicksoniaceae-related spores, for the main part of the Polish Lower Jurassic deposits indicate a subtropical, generally warm and humid climate However, one should bear in mind that there were some climatic fluctuations, for example in earliest Hettangian (Warrington, 1970; Orbell, 1973; Hubbard and Boutler, 2000; Guex et al. 2004). In contrast to this, McElwain et al. (1999) suggested a fourfold increase of $\mathrm{CO}_{2}$ at the T/J boundary and a global warming as a consequence. It is possible, however, that the long-term Hettangian warming effect followed a brief cooling event at the Triassic/Jurassic boundary. Another climate shift occurred in the Late Pliensbachian times, when the "greenhouse" climate may have been punctuated by sub-freezing polar conditions and the presence of limited polar ice is evidenced by dropstones and glendonites (Price, 1999). Paleotemperature variations of Early Jurassic seawater point to a sharp recurrent temperature drop during the Late Pliensbachian (Rosales et al. 2004). Such rapid drops in temperature could be associated with glaciations and rapid regressions, possibly providing onsets for the following warming phases, transgressions and anoxic events in the Early Toarcian (Morard et al. 2003; Rosales et al. 2004;. Hesselbo et al. 2007), coupled with increased humidity. It is now well-established that the Early Toarcian was characterized by major disturbances to the carbon cycle, as evidenced by large carbon-isotope excursions.

\section{Materials and methods}

Studies on the distribution of palynomorphs and other kerogen particles in various depositional systems have been performed on 226 samples derived from 7 selected boreholes (Figs. 1, 3) from 


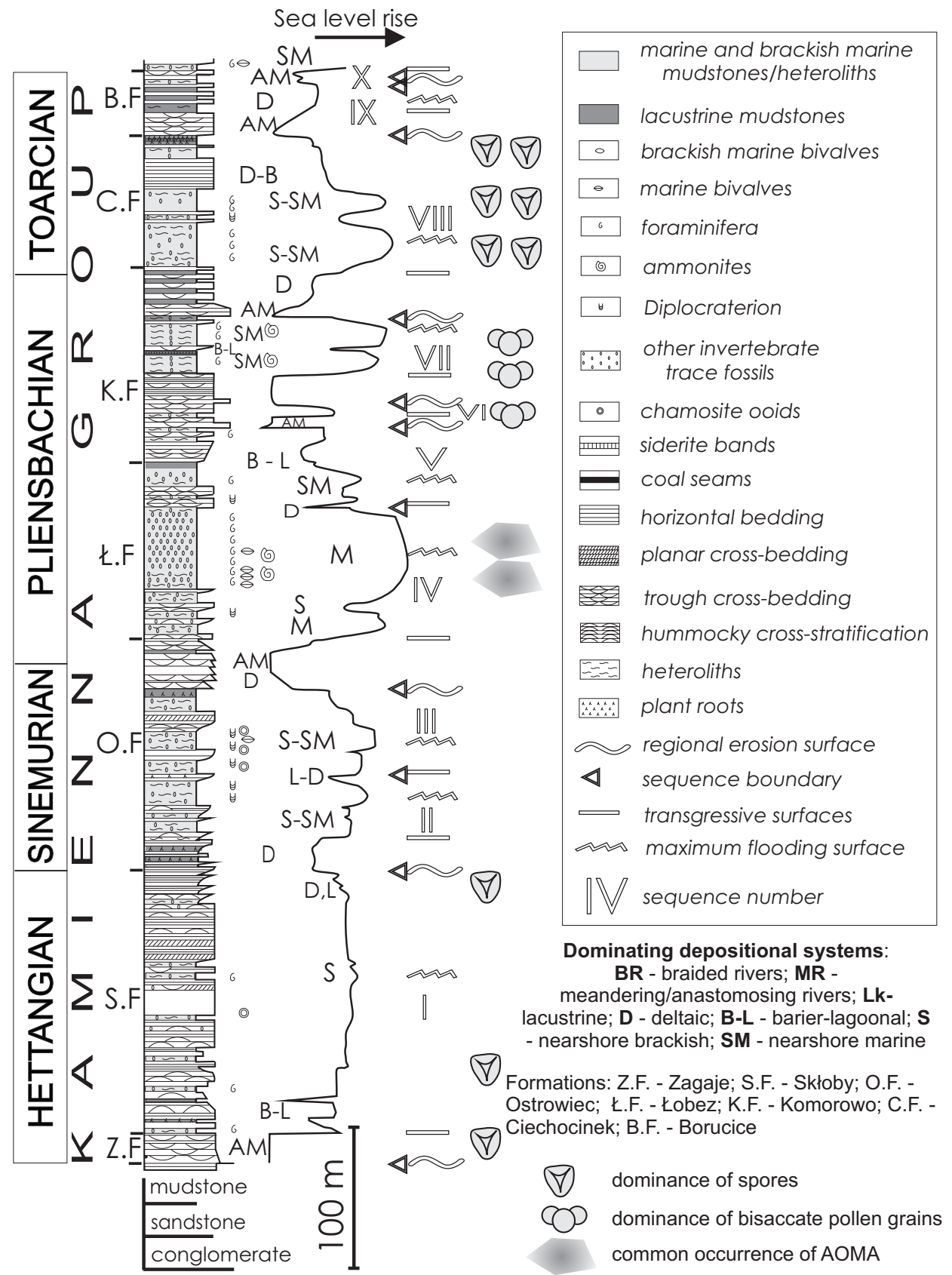

Figure 2. Synthetic profile of the Lower Jurassic of Poland (based on the Pomerania region), showing general facies, palaeoenvironments, sequence stratigraphy and general concentration in the profile of selected palynomacerals: spores, bisaccate pollen grains and AOMA (Amorphous Organic Matter of Aquatic Origin) in the profile, indicating the general palaeoclimatic and bathymetric conditions.

different regions and spanning stratigraphically entire Polish Early Jurassic. The following drillcores were included in this study: Gliniany Las 1 - Fig. 3, Gliniany Las II, Mroczków, Zawada 3, Gorzów Wielkopolski IG-1, Kamieñ Pomorski IG-1 and Bartoszyce IG-1. All samples derive from mudstone-claystone lithofacies (clay to silt size fraction, i.e. $<63 \mathrm{~mm}$ ), as an uniform sampling tend to strongly reduce a "sediment fraction bias" (Rossignol 1969; Mudie, 1982). The samples were subsequently macerated in hydrofluoric acid. During the preparation of the organic residues, no chemical oxidation or deliberate physical separation was involved. The macerated residue was mounted in glycerine gel (at least three strew slides were prepared from one sample) and were subsequently studied in light transmission light microscope. Selected samples were additionally studied in SEM.

Further definition of palynomacerals (or palynological matter) follows that of Powell et al. (1990), Batten (1996), with some amendments based on Van Bergen and Kerp (1990) and Tyson (1993, 1995).

\section{Results}

Generally, palynomacerals in the Lower Jurassic of Poland are rich and show strong dominance of terrestrial material (with exception of some Early Pliensbachian intervals in Pomerania). Palynomacerals found in the Lower Jurassic of Poland comprises the following elements:

\section{Palynomorphs}

1.1. - Spores - they are produced by pteridophyte, inhabiting usually more humid areas (Tyson, 1993). Only miospores are discussed in the present paper, the Early Jurassic megaspores of Poland (characterized by Marcinkiewicz, 1971) are statistically insignificant in the material studied. The most common miospores are represented by trilete fern spores (Pl. 1: 1, 2, 3, 4), sometimes they occur in tetrads (Fig. 4: 1) or sporangia.

1.2. - Bisaccate pollen grains - they are produced by a larger spectrum of plants than spores, particularly by conifers. These pollen grains have air sacs, which suggest wind pollination and is responsible for wide dispersion of these palynomorphs (Pl. 1: 3, 5). Occurrences of monosulcate pollen grains (mostly Ovalipolis sp. in the lowermost Hettangian) were sporadic and statistically insignificant in the material studied.

1.3 - Dinoflagellate cysts and acritarcha (Fig. 4: 2, 3) - they are primarily restricted to shelf environments and they had a meroplanctonic lifestyle similar to that of fossil and modern cystforming dinoflagellates (Dufka, 1990).

2 - Phytoclasts (STOM), for definition see Batten (1996). Structured organic matter - STOM - herein it means plant detritus, it comprises wood (translucent - brown and opaque - black), opaque charcoal (although assignation of charcoal is a matter of controversy - Tyson 1995; Batten, 1996) and other dark to opaque phytoclasts, cuticles and other non-cuticular tissues.

We follow the conclusion of Tyson (1995) that dark to opaque granular phytoclasts do not show good structural preservation, 


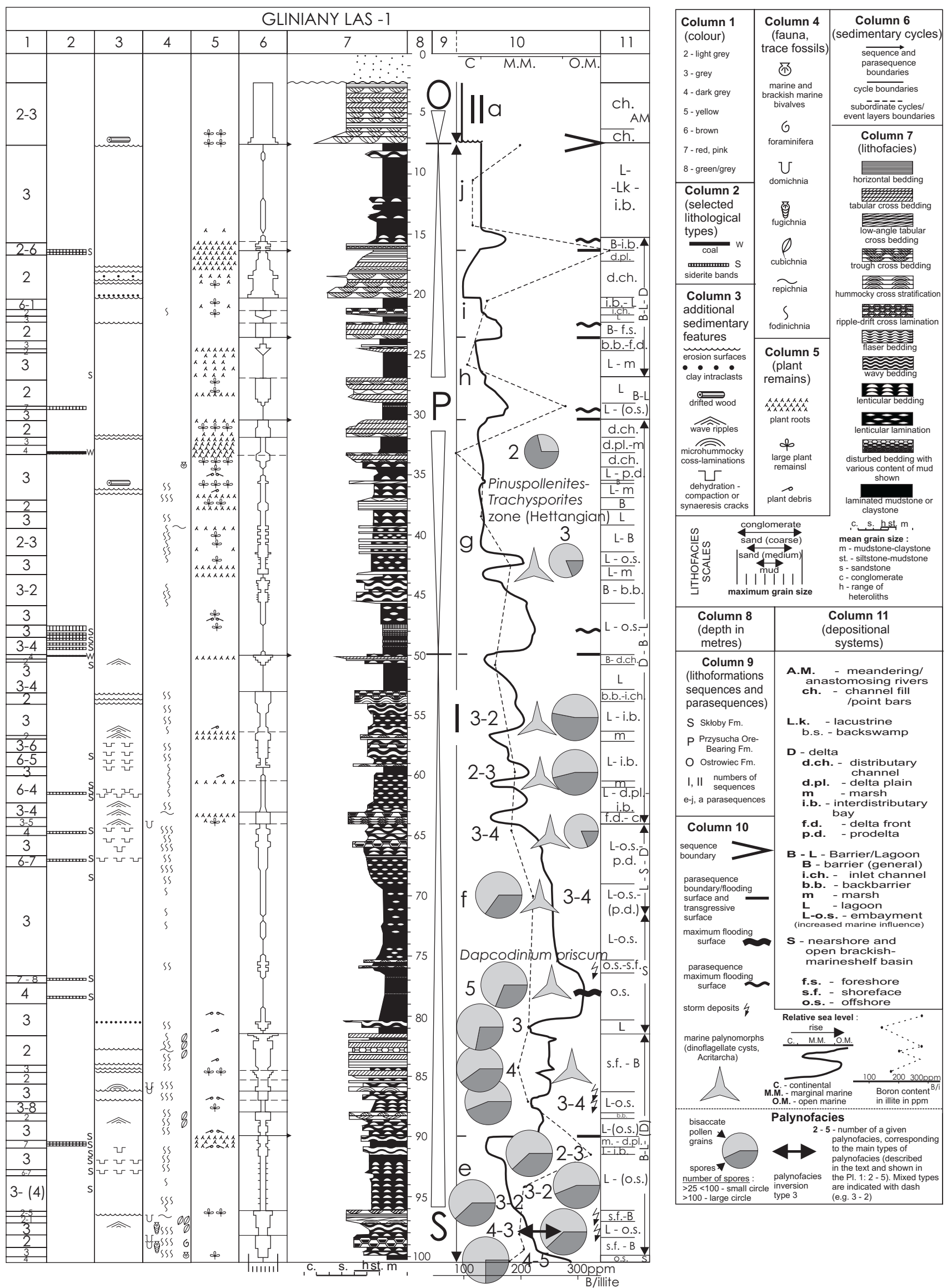

Figure 3. Detailed profile of the Gliniany Las I borehole (Holy Cross Mountains), one of the 35 cored boreholes with detailed sedimentological profile and interpretation (Fig. 1). Palynofacies are shown on the palaeoenvironmental background. 
at least in the transmitting light studies. Therefore it is hard to distinguish STOM from amorphous organic matter of terrestrial derivation (AOMT). Opaque phytoclast material is mainly derived from the oxidation of translucent woody material during prolonged transport, post-depositional alteration or wild fires (charcoal) Tyson (1993). Angular, lath-shaped fragments point to a structured phytoclasts, usually charcoal, which was proven in the SEM studies - Fig.4: 4

3 - Amorphous organic matter (AOM) is divided into AOMT (amorphous matter of terrestrial derivation, dark and usually opaque, occurring most often in rounded fragments) and AOMA (amorphous organic matter of aquatic origin, mostly light and translucent). AOMT embraces heterogenous, fluorescent amorphous organic matter, humic gel and resin (Tyson, 1995). AOMA (amorphous matter of aquatic origin) is usually of planctonic/bacterial origin (Batten, 1996) and it shows "spongy", translucent structure and diffusive outlines (P1. 1:6). Translucent AOMA dominate in the marine deposits (Tyson, 1995). It is not determined if it is of plant or animal origin.

Distribution of the Early Jurassic palynomacerals in Poland are related to the climatic conditions, regional palaeogeography/ palaeoenvironments and local palaeoenvironments (indicated in previous studies - Pieñkowski, 2004):

Climatic conditions: a high dominance of spores in the whole Polish Basin is observed in the Lower Toarcian (in average only $20 \%$ of bisaccate pollen grains against $80 \%$ of spores), which is a striking contrast to the rest of the geologic profile (Fig. 2). Strong spore domination as observed in the Lower Toarcian sediments is obviously associated with palaeoclimatic factors - climate at that time must have been much warmer and much more humid (perhaps, with exception of the lowermost part of the tenuicostatum biochronozone) than during other Early Jurassic intervals. The bisaccate pollen grain/ spore ratio in the Lower Toarcian deposits in Poland is always strongly biased towards spores, which dominate even in the brackish-offshore settings. This is concordant with Morard et al. (2003) and Rosales et al. (2004) and also Wang (2002) noted that the youngest Early Jurassic (likely Toarcian) flora the Early Jurassic Hsiangchi Formation from China point to a particularly warm and humid climate. On the other hand, Wang et al. (2005) postulated warm but somewhat drier conditions for Toarcian of Quaidam Basin, but stratigraphic precision does not allow to distinguish between the Lower and Upper Toarcian strata. It is possible that local climatic changes may have caused observed floral changes in China.
To a lesser extent, also Hettangian deposits show in some sections higher abundance of spores.

On the other hand, Late Pliensbachian palynofacies is characterized by strong dominance of bisaccate pollen grains (in average some $70 \%$ of bisaccate pollen grains to only $30 \%$ of spores). Dominance of pollen grains in Late Pliensbachian deposits (particularly in Eastern Poland) is clearly associated with drier and colder climate (Fig. 2) as coniferous source areas were generally drier, colder or higher than the habitats of pteridophyta. Macroflora found in the outcrops of Late Pliensbachian deposits shows dominance of coniferous forests at that time, some trunks attain $1 \mathrm{~m}$ of diameter.

Seasonal changes are characteristic of certain types of climate and they may have had an impact on the Jurassic palynofacies. Pieñkowski (2004) indicated recurrent palynofacies alterations in some laminated, varve-like mudstones (lagoonal/interdistributary bay deposits) with altering light- and dark-grey laminae. Light-grey, more silty laminae contain sparse, oxidized phytoclasts, including charcoal fragments (Fig. 5). On the other hand, dark-grey laminae contain numerous and much larger, translucent phytoclasts (cuticleand some wood). Pollen grain/spore ratio is similar in both types of laminae. Varve-like lamination reflects probably seasonal changes - light laminae represent drier seasons with wild fires, better drainage in nearby swamps or marshes and contain abundant oxidized organic matter. The dark lamina with abundant translucent plant tissue likely correspond to a wet seasons with poor drainage (high water level) in nearby swamps or marshes and intense vegetation. This example shows a "micro-scale" palynofacies fluctuations determined by seasonal changes, although a bulk sample containing both light and grey lamina shows a typical "lagoon" palynofacies characteristics. However, by taking a sample from only a single lamina one can obtain a spurious picture of a general palynofacies character.

Regional palaeogeography: regional palaeogeographical/ palaeoenvironmental differences are observed: samples from Western Poland (particularly Pomerania region) contain relatively more spores, while samples from the Eastern Poland (particularly the Baltic Syneclise region) are relatively rich in bisaccate pollen grains (again, with exception of Lower Toarcian assemblages, where spores always dominate). This is probably associated with regional climate fluctuations, associated with proximity of the West European Sea (Pomerania), and, on the other hand more continental climate (and possibly higher altitudes) in the East (Fig. 1).

Local palaeoenvironment/depositional systems: taking in account the general background of the climatic changes and regional
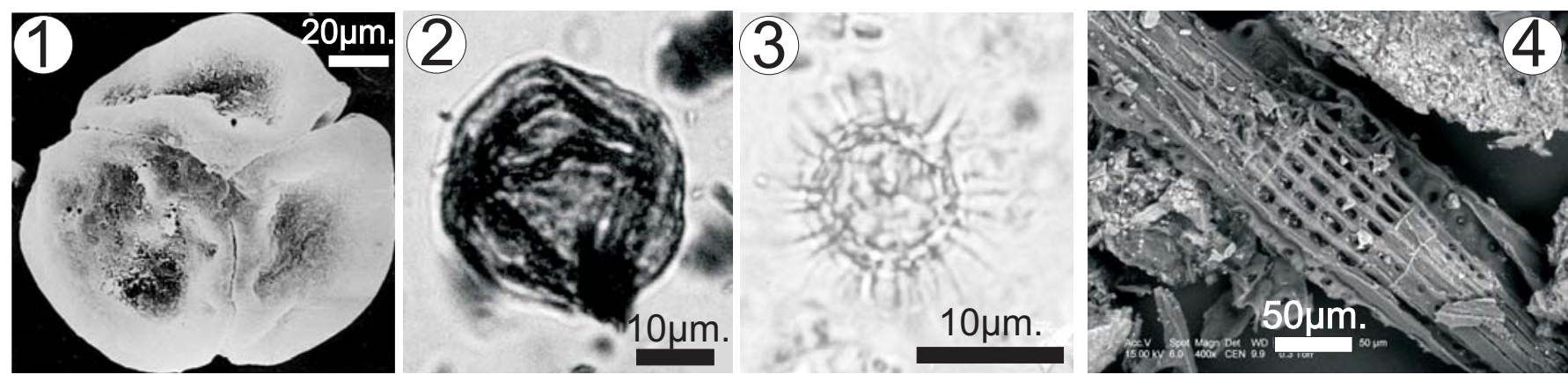

Figure 4. Selected palynomacerals: 1 - spore tetrad (SEM), Kamieñ Pomorski IG -1 borehole, depth 678.6 m, basal Hettangian; 2 dinoflagellate cyst (light micograph), Kamieñ Pomorski IG-1 borehole, depth 180.3 m, Lobez Fm., Lower Pliensbachian; 3 - acritarch (light mocrograph), Kamieñ Pomorski IG 1 borehole, depth 253.9 m, Lobez Fm., Lower Pliensbachian; 4 - charcoal with characteristic structure (SEM, photo L. Marynowski), Kamieñ Pomorski IG-1 borehole 

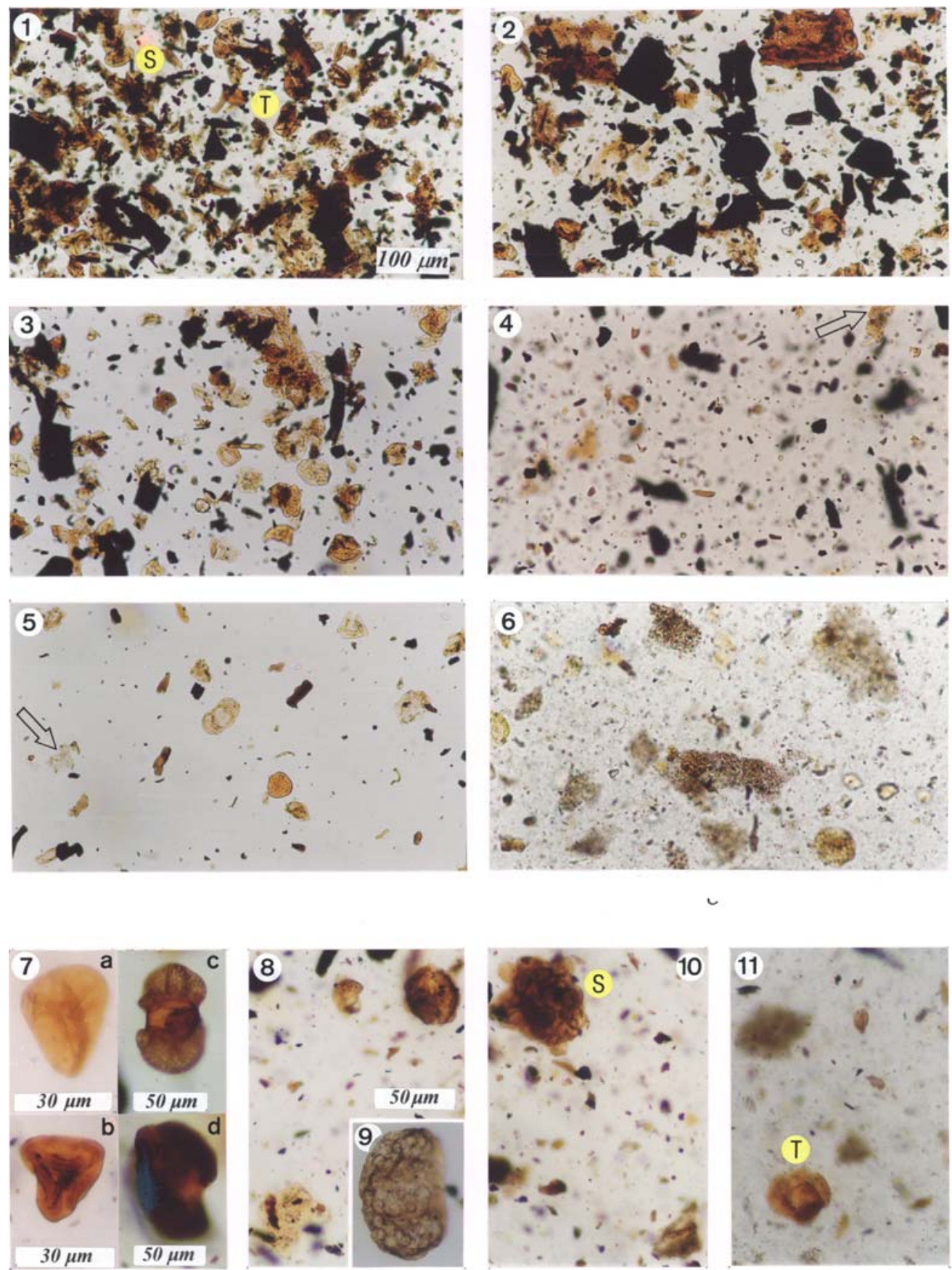

Plate 1. Typical palynofacies associations of the epicontinental Lower Jurassic of Poland. 1 alluvial plain/lacustrine palynofacies (Zawada PA-3 borehole, depth 97.8 m, Zagaje Fm., Lower Hettangian) - very abundant STOM (both translucent and opaque), very abundant spores (with tetrads - T and sporangia S); 2 - delta plain palynofacies (Gliniany Las 1 borehole - Fig. 3, depth $33.1 \mathrm{~m}$, Przysucha Ore Bearing Fm., Upper Hettangian), abundant STOM (both translucent and opaque), relatively more opaque STOM and AOMT than in palynofacies 1, dominance of spores; 3 - lagoon palynofacies (Gliniany Las 1 borehole - Fig. 3, depth $80.8 \mathrm{~m}$, Skloby Fm., Middle Hettangian), abundant translucent STOM (mostly cuticle), less frequent opaque STOM, numerous sporomorphs (in this sample bisaccate pollen grains dominate); 4 -foreshore-shoreface palyno-facies (Gorzów Wielkopolski IG-1 borehole, depth 1108,6 m, Skloby Fm., Middle Hettangian), dominance of fine, dispersed opaque STOM (with high occurrence of charcoal), palyno-morphs are mechanically corroded or destroyed (arrow indicates disintegrated bisaccate pollen grain); 5 - offshore/open brackish shelf (Gliniany Las I borehole - Fig.3, depth 77.4 m, Skloby Fm., Middle Hettangian, maximum flooding surface), very sparse STOM (mostly small

opaque fragments), sparse pollen grains which dominate over spores, occurrence of dinoflagellate cysts (arrowed - disintegrated cyst) and acritarchs; 6 - offshore fully marine shelf(Kamieñ Pomorski IG-1 borehole, depth 279,2 m, Lobez Fm. with ammonites., Lower Pliensbachian) - dominance of spongy, translucent AOMA with diffused edges, rare pollen grains either disintegrated or covered with epibiont growths (the pollen grain at the lower edge of the photo), occurrence of dinoflagellate cysts and acritarchs. Scale for 1 to $6-100 \mu m$, same as photo 1 .

Palynofacies inversions: 7 - colour contrasts of the same sporomorph taxons: 7a, b-spore Concavisporites intriastriatus (Nilsson) Ariang showing dark yellow (7a) or orange-brown colour (7b); 7 c, d-bisaccate pollen grain cf. Vitreisporites pallidus (Reissinger) Nilsson showing pale orange (7c) and dark-brown (7d) colours. All these sporomorphs showing wide range of colours derive from one sample (Kamieñ Pomorski IG-1 borehole, depth $400.2 \mathrm{~m}$, Upper Sinemurian, brackish-marine embayment deposits); 8 - palynofacies inversion type 3 in the same sample - on the typical background of palynofacies 5 (brackish offshore-embayment) with translucent AOMA (lower left corner) the tetrad is visible (upper right corner); 9 - the same sample - epibiont (likely algae of fungal) growths on the surface of corroded bisaccate pollen grain, scale same as photo 8; 10 - palynofacies inversion type 3 (Kamieñ Pomorski IG-1 borehole, depth 277.5 m, Lower Pliensbachian, fully marine offshore shelf deposits with ammonites), palynofacies "6" with translucent spongy AOMA and with sporangium (S), scale same as photo 8; 11 - palynofacies inversion type 3 (Kamieñ Pomorski IG-1 borehole, depth 279.2 m, Lower Pliensbachian, fully marine offshore shelf with ammonites), typical palynofacies " 6 " with translucent spongy AOMA, tetrad (T) is visible, scale same as photo 8. 


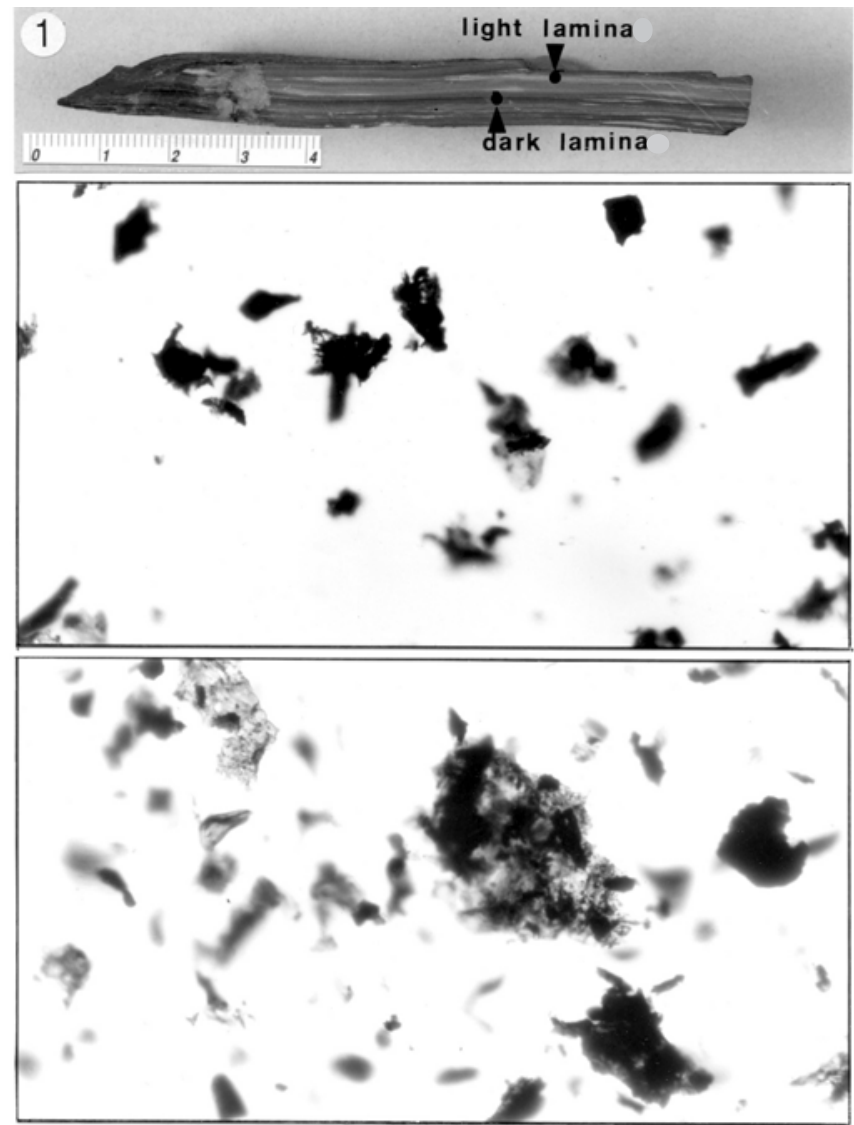

Figure 5. Laminated, varve-like mudstone (Kamieñ Pomorski IG 1 borehole depth 637.6 m, Lower Hettangian, Skloby Fm., lagoon/interdistributary bay environment), showing altering light and dark laminae, likely corresponding to seasonal changes. Palynofacies from the light lamina (upper photo) shows oxidized STOM (including numerous charcoal particles), sparse translucent STOM and sparse palynomorphs; these laminae contain more silt and less organic matter. Palynofacies of the dark lamina (lower photo) shows numerous translucent STOM (cuticle and wood), sparse oxidized organic matter and more palynomorphs; these lamina contain more clay and organic matter. Light laminae correspond probably to a dry season, while dark laminae represent wet seasons. Palynofacies show marked difference.

palaeogeographical differentiation, abundance and settling rate of palynomorphs and other kerogen elements is thought to be mainly controlled by local palaeoenvironmental conditions (sedimentary processes), thus the certain palynofacies can be attributed to certain palaeoenvironments. Generally, sporomorphs are most numerous in delta plain and fringing lagoonal deposits (Pl. 1: 2, 3). In the total material studied, bisaccate pollen grains show a slight dominance over spores (55\% to $45 \%)$. The ratio pollen grain/spores in marginalmarine and marine environments is taken in this paper as one of palynofacies indicators of a distance from the shore, although it must be taken with caution. Spores show dominance (in average some $70 \%$ to $30 \%$ ) in horizons with traces of vegetation (marshes with palaeosols and plant roots), which is expected in the places located near the parent pteridophyte flora. Spores are mainly produced in low lying swampy deltaic-alluvial plain areas and are common in palaeoenvironments situated close to these areas (Pl. 1: 1, 2, 3). This rule is well-known from previous works (Muir, 1964; Tyson, 1993,
1995; Batten, 1996; DeBusk, 1997). According to Reynolds et al. 1990 , further distribution of sporomorphs is influenced primarily by water depth and current velocity. Presence of sporangia, including tetrads (Pl. 1: 1), points to a short distance of transport because of their vulnerability to dynamic factors such as currents or waves. Therefore they usually indicate proximity to vegetated areas - except for the case of palynofacies inversion discussed below. In high-energy environments (both fluvial and nearshore) sporomorphs are often mechanically destroyed (Pl. 1: 4), therefore in high-energy nearshore zones the spores are relatively more frequent than bisaccate pollen grains, because they are more robust than pollen grains and they can be positively selected by turbulent hydrodynamic conditions. On the other hand, the widespread distribution of bisaccate pollen grains (besides their generally higher frequency), reflects the fact that they are the most buoyant and most easily transported of all sporomorphs, therefore they can be found even in distal offshore settings (Pl. 1: 5, 6). According to many authors (Hopkins, 1950; Brush and Brush, 1972; Melia, 1984; Traverse, 1988; Horowitz, 1992; Rousseau et al. 2006) bisaccate pollen grains are suited to long distance dispersal by wind and become preferentially concentrated in more fine-grained and deeper water sediments, either of marine or lacustrine origin.

Both sporomorphs and bisaccate pollen grains which are found in quiet offshore environment (both brackish and fully-marine) frequently show biogenic corrosion or epibiont (likely fungal or algal) growths (Pl. 1: 6, 9).

Oxidized black STOM, including charcoal (Fig.4: 4) is widely distributed in deltaic and high energy foreshore-shoreface facies (Pl. $1: 2,4)$. It is largely due to its buoyancy (Whitaker, 1984) and durability for decomposing. Charcoal produced by wildfires in the Lower Jurassic of Poland was found by Reymanówna (1993).

Wood is especially abundant in alluvial plains and in deltaic environment (Pl. 1: 1, 2). Coarse phytoclast material $(>1 \mathrm{~mm})$ is usually only dominant in high, first and second order, headwater streams (Minshall et al. 1985). Accumulations of medium to coarse grained plant detritus and recycled coal and lignite debris are apparently common in the swash zone of barrier beaches near the mouths of the Mississippi (Burgess, 1987), which is in concordance with observed high frequency of charcoal and oxidized wood fragments in delta plain and particularly foreshore-shallow shoreface environment (Pl. 1: 2, 4). Rounded opaque fragments of AOMT (Pl. 1: 5) can be also frequent in marginal marine and littoral facies Bustin (1988).

Cuticle (Pl. 1: 2, 3) is most common in lagoonal and deltaic (marsh) deposits. Fisher (1980) considers that the cuticle is especially characteristic of facies resulting from the settling out of flotation and suspension loads under low energy conditions.

Acritarcha and dinoflagellate cysts - if appear - occur in statistically insignificant amount in the Early Liassic material from Poland. However, their appearance is of big qualitative significance as they point to marine influences. Most studies have consistently demonstrated that a relative abundance of small micrhystridid Acritarcha occurring in the material studied is most characteristic of shallow water marginal marine conditions (Prauss, 1989). This seems to occur mainly in brackish marginal facies. As far as dinoflagellate cysts are concerned, there is no simple relationship between their abundance, diversity and inferred "marinity" of the environment. Generally, they indicate marine or brackish-marine environment. 
Light-brown to pale yellow and white AOMA of a spongy appearance (Batten, 1996) constitutes the most characteristic palynomaceral for fully-marine, offshore settings (Pl. 1: 6).

Last but not at least, frequency of certain palynomorphs may be influenced by redeposition (Batten, 1991). As indicated by taxonomic studies, number of sporomorphs derived from older (than Jurassic) systems was insignificant in the material studied. However, in places intraformational redeposition took place. This is of importance for colour of the sporomorphs (which will be discussed later), but still this process was not significant for quantitative properties of the Lower Jurassic palynofacies of Poland.

Based on the above characteristics, certain palynofacies have been linked to the prior determined palaeoenvironments (depositional systems). Six types of palynofacies have been distinguished:

1. Alluvial plain (Pl. 1: 1) - only mudstone/claystone samples were studied, thus they represent only alluvial plain fines deposited in lacustrine, distal crevasse or levee subenvironments. Generally, they show very abundant palynological matter, usually dominated by spores (in average $57 \%$ of spores to $43 \%$ of bisaccate pollen grains), presence of tetrads and sporangia (Pl. 1: 1). It should be noted that locally bisaccate pollen grains can show significant share, which largely depends on the local vegetation. Phytoclasts are very abundant and diversified, both translucent (cuticle, wood) and opaque (representing both oxidized "wood", charcoal or AOMT);

2. Delta plain (Pl. 1: 2) - abundant translucent (mostly cuticle and wood) to opaque phytoclasts (including more abundant charcoal than in the alluvial plain sediments), abundant sporomorphs, tetrads, sporangia, spores dominate over bisaccate pollen grains - in average $65 \%$ of spores to $35 \%$ of bisaccate pollen grains, sporadic presence of dinoflagellate cysts and acritarchs;

3. Lagoon (including delta front) - (Pl. 1: 3) - abundant sporomorphs, usually balanced pollen/spores ratio (in average $54 \%$ of bisaccate pollen grains to $46 \%$ of spores, but this ratio may vary considerably depending on the fluvial input), cuticle are abundant, moderate amount of other phytoclasts, relatively rare dark phytoclasts, rare dinoflagellate cysts and acritarchs;

4. Shoreface - foreshore (Pl. 1: 4) - common dispersed fragments of opaque phytoclasts (mostly charcoal), low to moderate content of sporomorphs, in lower energy environments bisaccate pollen dominate (in average $67 \%$ of bisaccate pollen grains to $33 \%$ of spores), while in high energy foreshore-shallow shoreface environment this ratio is usually reversed due to the more robust structure of spores resistant to mechanical destruction (Pl. 1: 4). Rare dinoflagellate cysts and acritarchs are observed;

5. Offshore brackish marine (Pl. 1: 5) - rare translucent AOMA, rare very small and rounded fragments of opaque phytoclasts (including charcoal), rare sporomorphs (bisaccate pollen grains dominate over spores - in average $67 \%$ of bisaccate pollen grains to $33 \%$ of spores), occasionally palynomorphs show biogenic corrosion and are covered by epibiont (likely algal or fungal) growths (Pl. 1: 9), relatively more common occurrences of dinoflagellate cysts and acritarchs;

6. Offshore marine (Pl. 1: 6) - common translucent, "spongy" AOMA with diffused edges, rare bisaccate pollen grains, spores absent or very rare - in average $73 \%$ of bisaccate pollen grains to $27 \%$ of spores (except for palynofacies inversions), palynomorphs often show biogenic corrosion and are covered by epibiont (likely

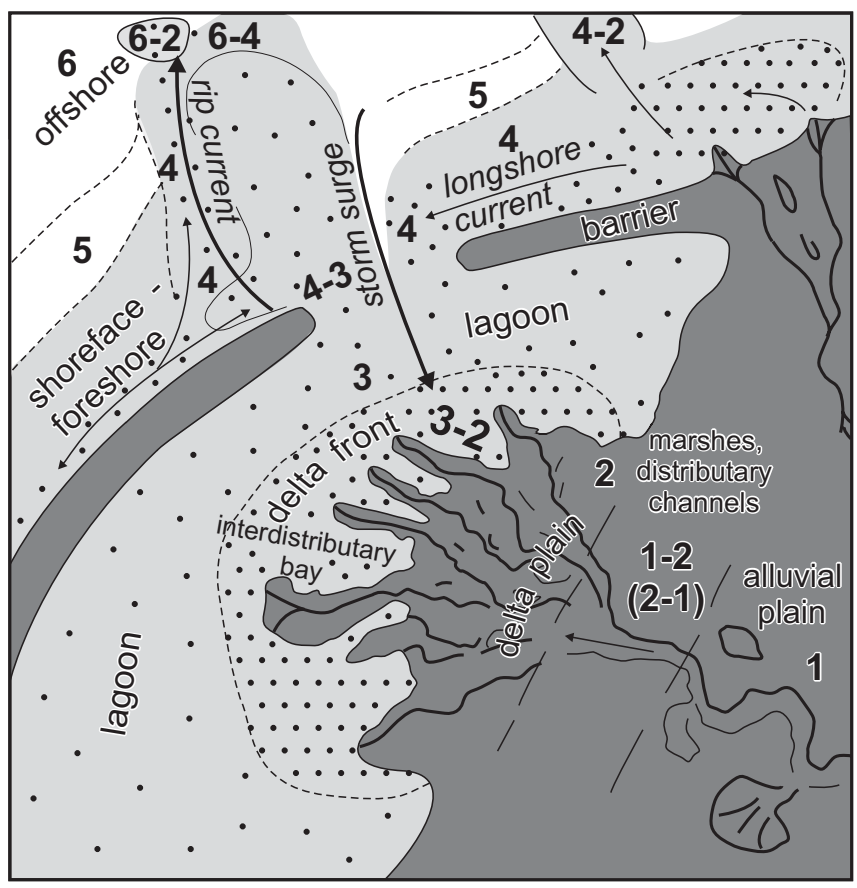

Figure 6. Sketch showing spatial distribution of main palynofacies associations on the palaeoenvironmental background. Dots represent concentrations of STOM (phytoclasts, including charcoal) and spores. The numbers represent successive palynofacies associations 1-6 (see text and Pl. 1).

algal or fungal) growths (Pl. 1: 6, 9), dinoflagellate cysts and acritarchs are relatively more common.

Spatial distribution of six palynofacies on the generalised paleoenvironmental background is presented on Fig. 6 .

\section{Palynofacies inversions}

The term palynofacies inversion was introduced by Pieñkowski (2004) and is further described herein to explain abnormal composition of palynomacerals (abnormal composition means significant difference both in content and appearance of certain palynomacerals from the typical "background" palynofacies, characterised as the 6 main palynofacies). Three types of palynofacies inversions have been distinguished (Fig. 7):

\section{Inversion type 1 - contrasting palynomorph colour}

This inversion is characterised by the presence of palynomorphs of coeval palynomorphs, having different colours (Pieñkowski, 2004). The colours are conventionally identified with TAI (thermal alteration index), thus the colours are related to the burial history of the palynomorphs (Marshall, 1991). The background "thermal" colour of Early Jurassic palynomorphs (except for few places in the maximum tectonic burial zones) is the dark yellow to pale orange colours (Pl. 1: 1-6). However, in some samples palynomorphs representing the same taxons may show much darker orange-brownish down to dark-brown colour (Pl. 1: 7). This is explained by the different early burial setting. The "background", dark-yellow palynomorphs were finally settled in the sediment just after their release from the parent plant and their colour reflects mostly a thermal history. Others, showing darker 


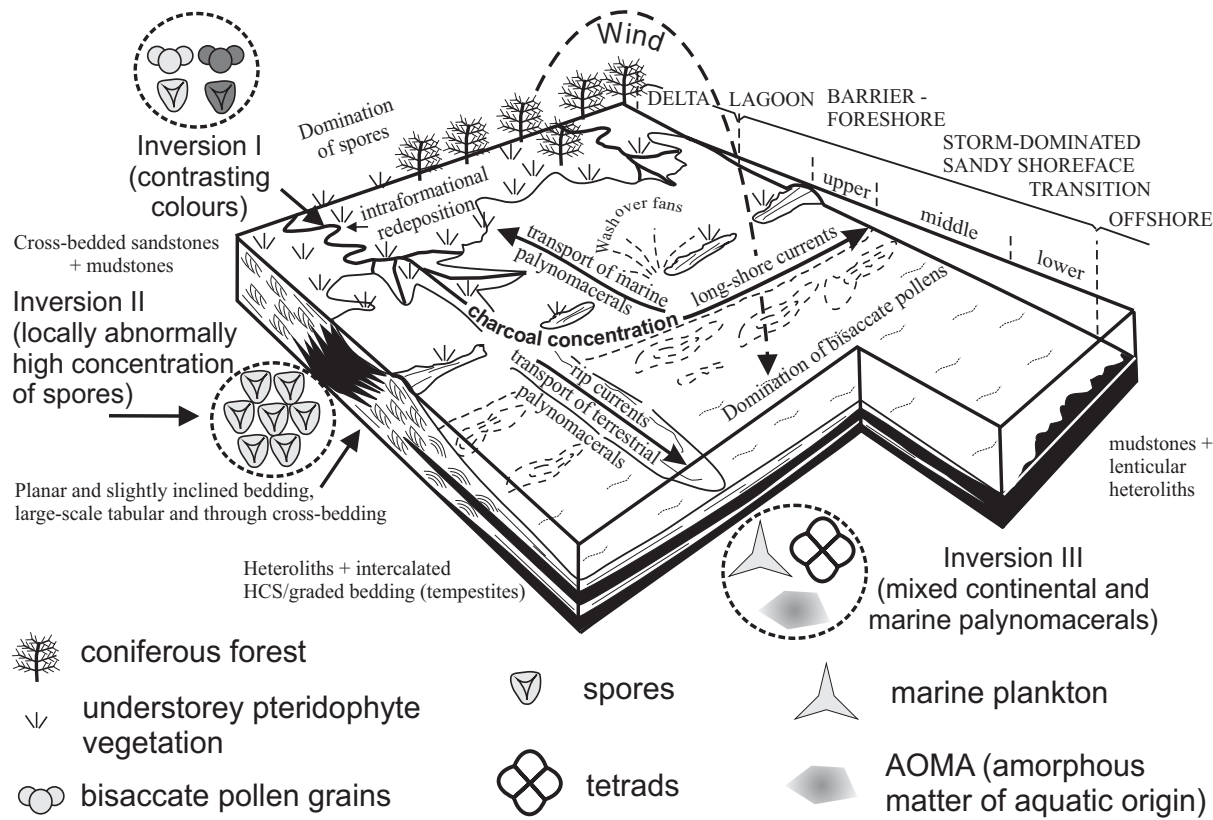

Figure 7. Three types of palynofacies inversions shown on the palaeoenvironmental background (depositional systems). The scheme shows also dispersion of some types of palynomacerals. with palaeosol horizons. Thus, it is interpreted that additional factor (hydrodynamic) must have been involved.

\section{Inversion type 3 - presence of sporangia and tetrads in open marine deposits}

This unusual mixture of different palynofacies elements (such as coexistence in one sample of spongy AOMA typical for offshore marine/brackish marine settings with tetrads and sporangia typical of alluvial-deltaic plains - Pl. 1: 8, 10,11) is explained by influence of offshore-oriented currents, which could introduce terrestrial palynofacies into an open marine environment (Pieñkowski, 2004). Presence of tetrads and sporangia in offshore settings was usually associated with distal storm deposits (tempestites). Strong, offshoredirected currents are capable of transporting colours, went through diagenetic (oxygenation) cycle in the alluvial plain/delta plain swamp/marsh environment and after getting dark they were redeposited to be finally incorporated in the sediment. Transport must have been relatively short as the darkened palynomorphs show little or no mechanical corrosion (Pl. 1: 7b, d). The whole primary burial - oxygenation - redeposition process took a time insignificantly short from the geologic point of view (so called "intraformational" redeposition). Although the burial period in swamp/marsh deposits was short enough to consider the palynomorphs as practically contemporaneous, they were significantly transformed as far as concerns their colours. This type of inversion points to the sedimentary "cannibalism" processes, associated both with lateral migration of channels, shifting of delta lobes, high-energy marine erosion caused by waves and currents (for example at the transgression surfaces). Moreover, this inversion shows that in certain cases colour measurements must be taken with due caution, as they may indicate something else than TAI reflecting epigenetic "tectonic" burial history.

\section{Inversion type 2 - abnormally high frequency of spores}

Occasionally, in lagoonal settings (delta fringing lagoons), up to 3000 of spores were found in one sample (in regard to its average volume and density). Such abnormal quantity of spores is explained by rapid decrease of current velocity at the mouth of distributary channel entering the delta-fringing lagoon. As the main vector of sporomorph dispersal is river water (Muller, 1959) sporomorph concentrations capable of diluting all other palynomorphs are generally restricted to the vicinity of active fluvio-deltaic sources (Tyson, 1993). Additionally, existence of delta-fringing lagoons at the river (distributary channel) mouth greatly enhances mass deposition of spores. Such abnormal abundance can be also be due to an abundance in ferns in the ecosystem, but such an extraordinary amount of sporomorphs is occasionally observed only in lagoonal/ lacustrine deposits and by an order exceeds average amount of spores observed in alluvial/deltaic plain sediments, even those associated the sediment far away from shore (Davidson-Arnott and Greenwood 1976). Moreover, bulk of terrestrial material is transported during periods of high discharge in rivers (floods) associated with storms, which is connected with so-called "wash-out" effect. Storm transport provides a potential mechanism by which plant material from alluvial/ deltaic settings, containing tetrads and sporangia, with may be occasionally flushed out and deposited in shelf environment (Hedges et al. 1988). Such possibility was also discussed by Tyson (1984, 1993): if the individual sporomorphs in a tetrad or sporangium are of low density, they should be capable of long distance flotation, and therefore other factors as the lower energy of the transporting and depositing mechanism play a crucial role in protecting the tetrad or sporangium from disaggregation. However, the clear association with storm deposits indicates that a high-energy agent could transport intact tertrads or sporangia. It seems that particularly a short time of flood/storm event was a key factor. It is also possible that sporangia and tetrads were transported offshore in large plant fragments and were released there in a post-storm, quiet weather conditions.

One should note that at many transgressive surfaces or flooding surfaces (smaller-scale transgressions at the parasequence boundaries) mixture of different palynomorphs can be also observed. Thus, transgression/flooding associated with regional sea-level rise can be also indicated as a process responsible for this kind of inversion, it is related to the reworking of previously deposited marginal-marine and alluvial plain sediments.

This type of inversion is by far the most common one in the Lower Jurassic of Poland. This is caused by the character of the shallow epicontinental basin, surrounded by deltaic or barrier-lagoonal facies, dominated by wave/current processes.

\section{Conclusions}

Rich palynomacerals obtained from the Polish Lower Jurassic deposits, together with precise sedimentological investigations, 
brought results useful for general palynofacies recognition particularly in continental and marginal-marine environments. In general, ratio of spores and bisaccate pollen grains significantly depends on climate and the relatively cooler and drier Late Pliensbachian climate resulted in dominance of pollen grains, while very warm and humid climate in the Early Toarcian times (to lesser extent also Hettangian) resulted in high dominance of spores. Regional environmental conditions (related to the distance to the shore, palaeorelief and drainage factors) resulted also in regional variation in the bisaccate pollen grain/spore ratio. In the Lower Jurassic strata of Western Poland (Pomerania), spores are generally more frequent than in Eastern Poland (Baltic Syneclise, Holy Cross Mountains), where bisaccate pollen grains dominate (except of the Lower Toarcian, where spores always dominate). Taking into account, climatic and regional factors, the spore/bisaccate pollen grain ratio can be taken as a general indicator of distance to the shore. Spores tend to be relatively more abundant in alluvial plain and deltaic plain environments than in the nearshore, and particularly, offshore environments. Cuticles are particularly common in the lagoonal and delta plain deposits, while charcoal and oxidized wood fragments are relatively most common in the high energy, nearshore environment and in the delta plain environment due to its buoyancy and resistance to biological/chemical degradation. Translucent, spongy AOMA is present in offshore deposits, being less frequent in brackish marine and more frequent in fully marine shelf environment. Miospores occurring in offshore environment show epibiontic growths and traces of biodegradation.

Six typical palynofacies assocations, linked to previously determined palaeoenvironments, have been distinguished.

Palynological inversions (Pieñkowski, 2004) are further described and three types of such inversions are distinguished: type one is connected with intraformational redeposition resulting in contrasting colours of miospores, two others are related to sedimentary processes: hydrodynamic entrapment of spores in delta-fringing lagoons (type 2) or insertion of characteristic terrestrial palynomacerals into offshore-shoreface environment due to storm resuspension processes associated with rip currents (type 3). The type 3 inversion may be associated with transgressions (including parasequence flooding events) and related reworking/redeposition processes. The type 3 inversion is the most common one.

Palynological inversions must be taken into account in the interpretation of both colour and palynofacies composition. In such cases, the "background" palynofacies in their regional and palaeoclimatic context must be taken into account when performing correct palaeoenvironmental interpretations.

\section{Acknowledgements}

This work was financed by the Polish scientific funds 2006/2007 as the project N307 $01131 / 0941$ and from the scientific funds of the Polish Geological Institute, project no. 6.10.0003.00.0. This is a contribution to IGCP project 506 "Marine and Non-marine Jurassic: Global Correlation and Major Geological Events".

\section{References}

Barski M., Leonowicz P., 2002, Dinoflagellates of Lower Juarassic outcrops at Kozlowice and Boroszów (southern Poland): Przegld Geologiczny,
50, 5, pp. 411-414.

Batten, D.J., 1973, Use of palynologic assemblage-types in Wealden correlation: Palaeontology, 16, pp.1-40

Batten, D.J. 1991, Reworking of plant microfossils and sedimentary provenance, in Morton, A.C., Toold, S.P., and Hanghan, P. D. W., eds, Geological Society Publications 57, pp. 79-90

Batten, D.J., 1996, Palynofacies and palaeoenvironmental interpretation, in Jansonius, J,. McGregor, D.C, eds, Palynology: principles and applications. American Association of Stratigraphic Palynologists Foundation, 3, pp.1011-1064

Brush, G.S., Brush, L.M. Jr, 1972, Transport of pollen in a sediment-laden channel: a laboratory study: American Journal of Science, 272, pp. 359381

Burgess, J.D., 1987, Provenance, preservation, and transport of the detrital "coffee grounds" of the Mississippi Delta: International Journal of Coal Geology, 7, pp. 135-145

Bustin R.M., 1988, Sedimentology and characteristics of dispersed organic matter in Tertiary Niger Delta: origin of source rocks in a deltaic environment: American Association of Petroleum Geologists Bulletin, 72, pp. 277-298

Chandler, M.A., Rind, D., and Ruedy, R., 1992, Pangaean climate during the Early Jurassic: GCM simulations and the sedimentary record of paleoclimate: Geological Society of America Bulletin, 104, pp. 543559

Combaz, A., 1964, Les palynofacies: Revue de Micropaléontologie, 7, pp. $205-218$

Dadlez, R., 1997, Epicontinental basins in Poland. Devonian to Cretaceous - relationships between the crystalline basement and sedimentary infill: Geological Quarternary, 41, pp. 419-432

Davidson-Arnott, RG.D., Greenwood, B., 1976, Facies relationships on a barred coast, Kouchibouguac Bay, New Brunswick, Canada. In: Davis R.A., Jr., and Ethington R.L., eds, Beach and nearshore sedimentation: Society of Economic Paleontologists and Mineralogists Special Publications, 24, pp. 149-168

DeBusk, G.H., 1997, The distribution of pollen in the surface sediments of Lake Malawi, Africa, and the transport of pollen in large lakes: Review of Palaeobotany and Palynology 97, pp. 123-153

Dufka, P., 1990, Palynomorphs in the Llandovery black shale sequence of the Praque Basin (Barrandian area, Bohemia): Ėasopis pro Mineralogia a Geologia., 35, pp. 15-31

Fisher, M.J., 1980, Kerogen distribution and depositional environments in the Middle Jurassic of Yorkshire U.K., in Bharadwaj, H.P., Singh, H.P. and Tiwari, R.S., eds, Proceedings of the $4^{\text {th }}$ International Palynological Conference: Lucknow 1976-1977, 2, pp. 574-580.

Graciansky, P.C. De, Dardeau, G., Dommerques, J.L., Durlet, C., Marchand, D., Dumont, T., Hesselbo, S.P., Jacquin, T., Goggin, V., Meister, C., Mouterde, R., Rey, J., Vail, P.R., 1998, Ammonite biostratigraphic correlation and Early Jurassic sequence stratigraphy in France: comparison with some U.K. sections, in De Graciansky, P.C., Hardenbol, J., Jacquin, T., Vail P.R., eds, Mesozoic and Cenozoic Sequence Stratigraphy of European Basins: Society of Economic Paleontologists and Mineralogists Special Publication, 60, Tulsa, pp. 583-622

Gradstein F., Ogg, J.G., Smith, A.G., Blecker, W. and Lourens, L.J., 2004, A new geologic time scale with special reference to Precambrian and Neogene: Episodes, 27, pp. 83-100

Guex, J., Bartolini, A., Atudorei, V., and Taylor, D. 2004, High-resolution ammonite and carbon isotope stratigraphy across the Triassic-Jurassic boundary at New York Canyon (Nevada): Earth and Planetary Science Letters, 225, pp. 29-41

Haq, B.U., Hardenbol, J., and Vail P.R., 1987, Chronology of fluctuating sea level since the Triassic: Science, 235, pp. 1156-1167

Hedges, J.I., Clark, W.A., and Cowie, G.L., 1988, Organic matter sources to the water column and surficial sediments of a marine bay: Limnology and Oceanography, 33, pp. 116-136

Hesselbo, S.P., and Jenkyns, H.C., 1998, British Lower Jurassic Sequence Stratigraphy, in De Graciansky, P.C., Hardenbol, J., Jacquin, T., Vail P.R., 
eds, Mesozoic and Cenozoic Sequence Stratigraphy of European Basins: Society of Economic Paleontologists and Mineralogists Special Publication, 60, Tulsa, pp.561-581

Hesselbo, S.P., Jenkyns, H.C., Duarte, L.V. and Oliveira, L.C.V. 2007, Carbonisotope record of the Early Jurassic (Toarcian) Oceanic Anoxic Event from fossil wood and marine carbonate (Lusitanian Basin, Portugal): Earth and Planetary Science Letters, 253, pp. 455-470

Hopkins, J.S., 1950, Differential flotation and deposition of coniferous and deciduous tree pollen: Ecology, 31, pp. 633-641

Horowitz, A., 1992, Palynology of Arid Lands: Elsevier, Amsterdam, $546 \mathrm{pp}$.

Hubbard, R.N.B.L., and Boutler M.C., 2000, Phytogeography and Palaeoecology in Western Europe and Eastern Greenland Near the Triassic-Jurassic Boundary: Palaios, 15, pp. 120-131

Makarewiczówna A., 1928, Etude sur la flore fossile du lias inférieur des environs d'Ostrowiec, PologneL: Travaux de la Société des Sciences et des Lettres de Wilno, L'Institut de Géologie, 3, pp. 1-49

Marcinkiewicz, T., 1971, The stratigraphy of the Rhaetian and Lias in Poland based on megaspore investigations: Instytut Geologiczny Prace., 65, pp. $1-58$

Marshall, J.E.A., 1991, Quantitative spore colour: Journal of the Geological Society, Vol. 148, pp. 223 - 233;

McElwain, J.C., Beerling, D.J., and Woodward, F.I. 1999, Fossil plants and global warming at the Triassic-Jurassic Boundary, Science, 285, pp. 13861390

Melia, M.B., 1984, The distribution and relationship between palynomorphs in aerosols and deep-sea sediments off the coast of northwest Africa: Marine Geology, 58, 345-371

Minshall, G.W., Cummins, K.W., Petersen, R.C., Cushing, C.E., Bruns, D.A., Sedell, J.R. and Vannote, R.L., 1985, Developments in stream ecosystem theory: Canadian Journal of Fisheries and Aquatic Sciences, 42, pp. 10451055

Morard, A., Guex, J., Bartolini, A., Morettini, E., and Wever, P. 2003, A new scenario for the Domerian - Toarcian transition: Bulletin de la Société géologique de France, 174, pp. 351-356

Mudie, P.J., 1982, Pollen distribution in recent marine sediments, Eastern Canada: Canadian Journal of Earth Sciences, 19, pp. 729-747

Muir, M.D., 1964, The Palaeoecology of the Small Spores of the Middle Jurassic of Yorkshire: Unpublished PhD Thesis, University of London, $234 \mathrm{pp}$.

Muller, J., 1959, Palynology of recent Orinoco Delta and shelf sediments : reports of the Orinoco Shelf expedition, volume 5: Micropalaeontology, 5, pp. 1-32.

Orbell, G., 1973, Palynology of the British Rhaeto-Liassic. Bulletin of the Geological Survey of Great Britain, 44, pp.1-44

Pieñkowski, G., 1985, Early Liassic trace fossils assemblages from the Holy Cross Mountains, Poland: their distribution in continental and marginal marine environments, in Curran H.A., ed., Biogenic Structures: Their Use in Interpreting Depositional Environments. Society of Economic Paleontologists and Mineralogists Special Publications, 35, pp. 37-51.

Pieñkowski, G., 1991, Eustatically-controlled sedimentation in the HettangianSinemurian (Early Jurassic) of Poland and Sweden: Sedimentology, 38, pp. $503-518$

Pieñkowski, G. 2004, The epicontinental Lower Jurassic of Poland: Polish Geological Institute Special Papers, 12, pp. 1-154

Pieñkowski, G. and Niedzwiedzki,G. (2009), Invertebrate trace fossil assemblages from the Lower Hettangian of So ${ }^{3}$ tyków, Holy Cross Mountains, Poland: Proceedings of the $7^{\text {th }}$ International Congress on the Jurassic System, September 6-18, 2006, Kraków, Poland, Volumina Jurassica V, pp. 89-104.

Powell, A.J, Dodge, J.D. and Lewis, J., 1990, Late Neogene to Pleistocene palynological facies of the Peruvian continental margin upwelling, Leg 112, in Proceedings of the Ocean Drilling Project, Scientific Results, Suess, E. and Von Huene, R., eds, College Station: Texas, 112, pp. 297321.
Prauss, M., 1989, Dinozysten-stratigraphie und Palynofazies im Oberen Lias und Dogger von NW-Deutschland: Palaeontographica Abteilung B, 241, pp. 1-124

Price, G.D., 1999, The evidence and implications of polar ice during the Mesozoic: Earth-Science Reviews 48, pp. 183-210

Reymanówna, M., 1991, Two conifers from the Liassic flora of Odrow ${ }^{1} \dot{c}$ in Poland, in Kovar-Eder, J., ed., Palaeovegetational development in Europe and Regions relevant to its palaeofloristic evolution: Proceedings, PanEuropean Palaeobotanical Conference, Vienna, Naturhistorisches Museum, Wien, pp. 307-310

Reymanówna, M., 1993, Forest fire in the lower Liassic of Odrow ${ }^{1}$, , Poland (abs): Plants and their Environment, Resumes des Communications presentees lors du Premier Congres Europeen de Paleontologie. Organismes - paleoenvironnement interactions, Universite de Lyon, p. 111 .

Reynolds, C.S., White, M.L., Clarke, R.T., Marker, A.F., 1990, Suspension and sinking of particles in flowing water: comparison of the effects of varying water depths and velocity in circulating channels: Freshwater Biology, 24, pp. 23-34.

Rosales, I., Quesada S., and Robles S., 2004, Paleotemperature variations of Early Jurassic seawater recorded in geochemical trends of belemnites from the Basque-Cantabrian basin, northern Spain: Palaeogeography, Palaeoclimatology, Palaeoecology, 203, pp. 253-275

Rossignol, M., 1969, Sédimentation palynologique dans le dommaine marin: Quaternaire de Palestine: etude de paléo-environnement. Notes et Mémoires sur le Moyen-Orient: Muséum National d'Histoire Naturelle, Paris, 10, 272 pp.

Rousseau, D.D., Schevin, P., Duzer, D., Cambon, G., Ferrier, J., Jolly, D., and Poulsen, U., 2006, New evidence of long distance pollen transport to southern Greenland in late spring: Review of Palaeobotany and Palynology, 141, 3-4, pp. 277-286

Traverse, A., 1988, Paleopalynology: Unwin Hyman, Boston, 600 pp.

Tschudy, R.H., 1969, Relationship of palynomorphs to sedimentation, in Tschudy, R.H. and Scott R.A., eds, Aspects of Palynology: Wiley, New York, pp. 79-96

Tyson, R.V., 1984, Palynofacies investigation of Callovian (Middle Jurassic) sediments from DSDP Site 534, Blake-Bahama Basin, western Central Atlantic: Marine and Petroleum Geology, 1, pp. 3-13

Tyson, R.V., 1987, The genesis and palynofacies characteristics of marine petroleum source rocks, in Brooks, J. and Fleet, A.J., eds, Marine Petroleum Source Rocks, Geological Society Special Publication, 26, pp. $47-67$

Tyson, R.V., 1989, Late Jurassic palynofacies trends, Piper and Kimmeridge Clay Formations, UK onshore and offshore, in Batten, D.J. and Keen, M.C., eds, Northwest European Micropalaeontology and Palynology, British Micropalaeontological Society Series: Ellis Horwood, Chichester, pp. $135-172$

Tyson, R.V., 1993, Palynofacies analysis, in Jenkins, D.G., ed., Applied Micropalaeontology: Kluwer Academic Publishers, Dordrecht, pp. 153191

Tyson, R.V., 1995, Sedimentary Organic Matter. Chapman \& Hall, London, $615 \mathrm{pp}$.

Van Bergen, P.F., and Kerp, J.H.F., 1990, Palynofacies and sedimentary environments of a Triassic section in southern Germany: W.J.J. Fermont and J.W. Weegink (eds), Proceedings of the International Symposium on Organic Petrology, Zeist, January 1990, Mededelingen Rijks Geologische Dienst, 45, pp. 23 - 37.

Wang, Y., 2002, Fern ecological implications from the Lower Jurassic in Western Hubei, China: Review of Palaeobotany and Palynology 119, 12, pp. $125-141$

Wang, Y., Mosbrugger, V., and Zhang, H., 2005, Early to Middle Jurassic vegetation and climatic events in the Qaidam Basin, Nothwest China: Palaeogeography, Palaeoclimatology, Palaeoecology 224, pp. 200 -216

Warrington, G., 1970, The stratigraphy and palaeontology of the "Keuper" Series in the central Midlands of England: Quarterly Journal of the Geological Society, 126, pp.183-223. 
Wcislo-Luraniec, E., 1991, Flora from Odrowaz in Poland - a typical Lower Liassic European flora, in Kovar-Eder, J., ed., Palaeovegetational development in Europe and Regions relevant to its palaeofloristic evolution, Proceedings, Pan-European Palaeobotanical Conference, Vienna: Naturhistorisches Museum, Wien, pp. 331-334

Whitaker, M.F., 1984, The usage of palynology in definition of Troll Field geology, in Reduction of Uncertainties in Innovative

\section{Grzegorz Pieñkowski, Assistant} Professor, Polish Geological Institute. Author and co-author of one book, four monographs and geological atlases, more than 50 papers on sedimentology of siliciclastic deposits, trace fossils and Jurassic sequence stratigraphy. 1984-1987 part-time Visiting Professor, Lund University, Sweden, from 2005 co-leader of the IGCP project 506, corresponding member of the International Subcommission

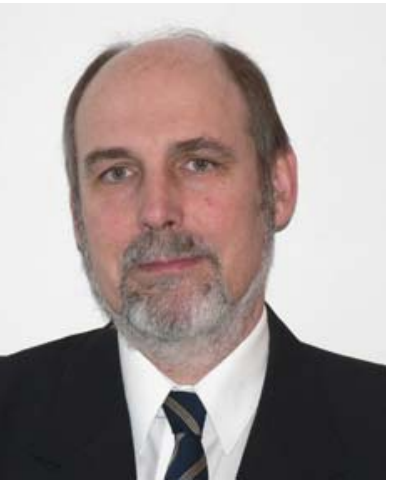

Marta Waksmundzka, Research Scientist, palynologist, Polish Geological Institute. Author and coauthor of 1 monograph and 10 reports on sporomorphs, their taxonomy and taphonomy and Triassic to Cretaceous palynostratigraphy. M.S., Ph.D., 1979, 90 , Warsaw University.

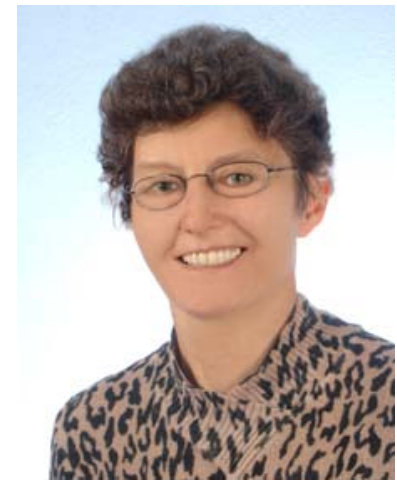
on Jurassic Stratigraphy. M.S., Ph.D., 1976, 82, Warsaw University, D.Sc., 2005, Jagiellonian University, Cracow. Between 1991 and 1996 Polish Consul-General in Sydney, Australia

reservoir Geomodelling: $6^{\text {th }}$ Offshore Northern Seas Conference and Exhibition, Stavanger 1984, Norsk Petroleums-forening, Paper G6, 44 pp.

ams, G.L., 1992, Palynology as a palaeoenvironmental indicator in the Brent Group, northern North Sea, in Morton, A.C., Haszeldine R.S., Giles, M.R., and Brown S., eds, Geology of the Brent Group: Geological Society of London Special Publication, 61, pp.203-212

\section{CALL FOR PAPERS}

Episodes is a quarterly science and news journal of the International Union of Geological Sciences (IUGS). It focuses on the publication of results of scientific research and other information addressing issues of interest to the global earth-science community. Special emphasis is given to topics involving geological aspects of population growth and economic development and their resulting impacts on or implications for society. As the principal publication of the IUGS, Episodes also carries information about IUGS scientific programs and activities to the extent necessary to communicate effectively with the worldwide IUGS constituency.

Contributions of the following types of manuscripts are solicited:

- Review papers

- News and views

- Scientific articles

- Letters to editor
- Conference reports

- Book reviews

- Information on training courses (especially those geared to participants from developing countries)

- Noteworthy new publications, including national or regional geological maps

Episodes also invites photos or other images for the front cover. Photos must be of high technical quality and tell an interesting geological story. A color transparency and one color print (at least $9 \mathrm{~cm} \times 12.6 \mathrm{~cm}$ ) are required for submission, which should be supplemented with a short explanatory paragraph (no more than 100 words).

Please address all contributions to:

\section{Dr. M. Jayananda - Editor}

Episodes

Geological Society of India

No.63, $12^{\text {th }}$ Cross, Basappa Layout

Gavipuram P.O., P.O. Box 1922

Bangalore - 560 019, INDIA

Phone: +91-080-22422943; Telefax: +91-80-26613352

Email: episodes.editor@gmail.com 